\title{
Gram per Kilogram
}

National Cancer Institute

\section{Source}

National Cancer Institute. Gram per Kilogram. NCI Thesaurus. Code C69104.

A unit of a mass fraction expressed as a number of grams of substance per kilogram of mixture. Gram per kilogram is also used as a dose calculation unit to express a quantity of substance in grams per one kilogram of body mass. 